\title{
A Geological Understanding of Lake Michigan's High Lake Levels
}

\section{Lake Level in the Historical Record}

\section{Seasonal change}

Lake Michigan rises and falls annually about 1 foot, with the lowest average monthly lake level in the month of February and the highest in early to mid-July. The graph shows the average monthly elevation using historical data from 1918 to 2019.

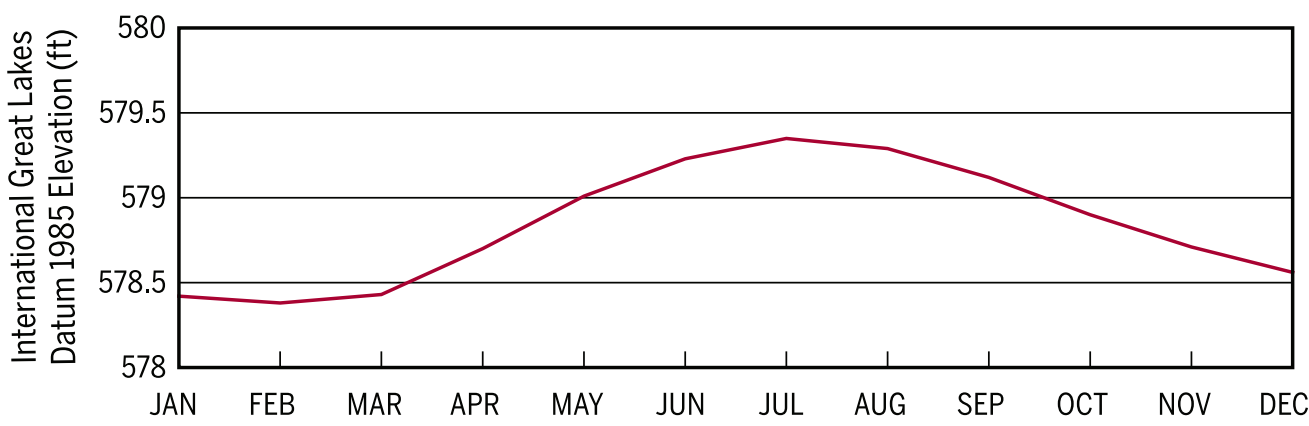

\section{Annual change}

The historical record of lake-level change extends back into the early 1800 s, with the most accurate instrumental data extending from the early 1920s to today. The average annual change from one year to the next, using data from the last century is about 0.5 feet. Some rapid rises occurred over several years from 1926 to 1929,1949 to 1952 , 1964 to 1973, and the more recent change from 2013 to 2019. This latter rise is a little more than 4 feet.

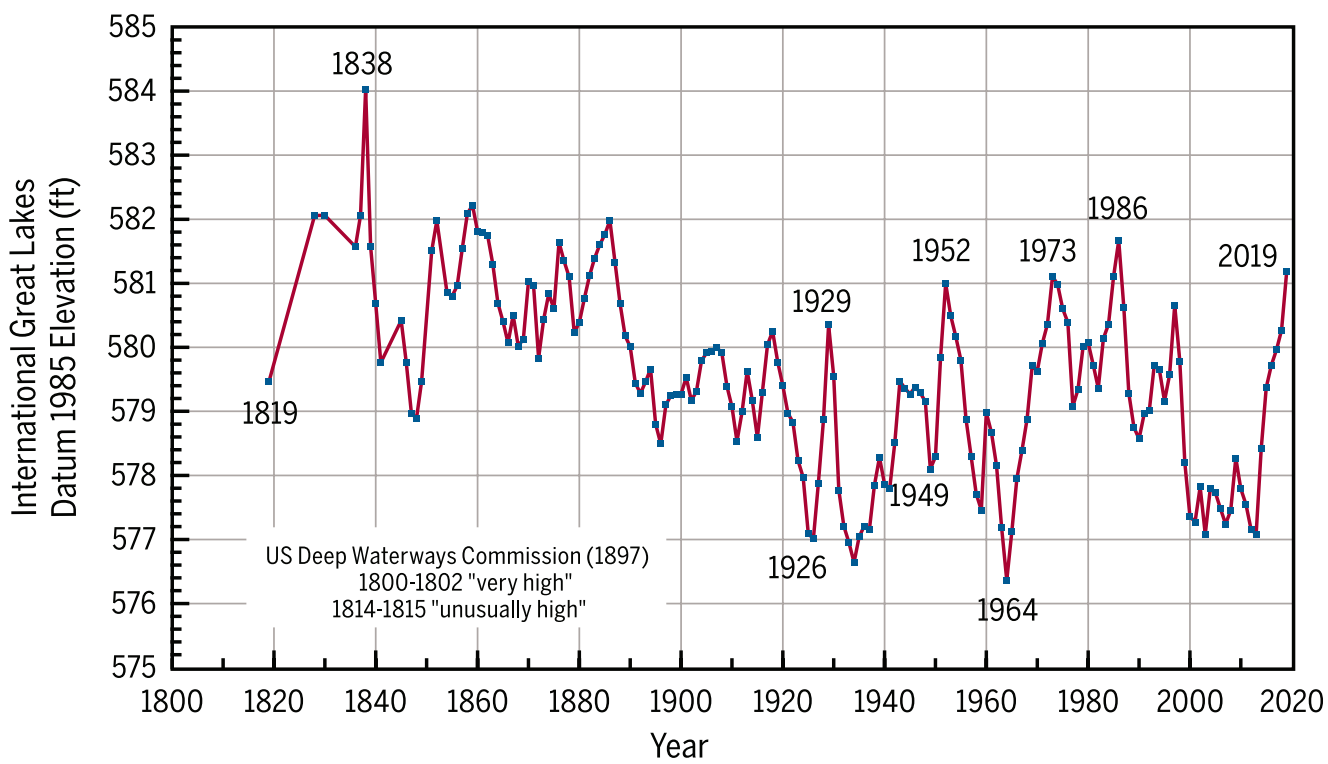

\section{CURRENT} \section{SITUATION}

Crashing waves, eroding

seawalls, collapsing roads, and

disappearing beaches have

become a common sight along

the Lake Michigan shoreline

during the past months.

Research studies conducted

on the changing levels of the

Great Lakes by Todd Thomp-

son, Director of the Indiana

Geological and Water Survey,

and his colleagues can help

evaluate recent changes to the

coast in the context of long-

term lake-level change.

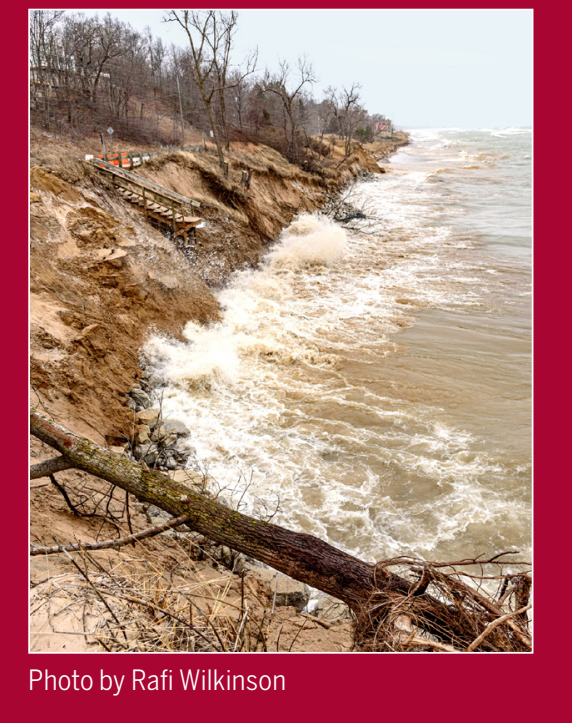

By Todd A. Thompson and Erin P. Argyilan DOI 10.14434/ijes.v2i0.31135

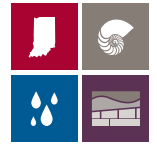

INDIANA GEOLOGICAL \& WATER SURVEY

INDIANA UNIVERSITY 


\section{Lake Level in the Geological Record}

\section{Studying the Geological Record}

The historical instrumental record for Lake Michigan is too short to recognize long-term patterns of lake-level change. For that, it must be extended back into geologic time. Fortunately for Lake Michigan and the upper Great Lakes, their coastlines are rimmed by remnants of earlier shorelines (known as beach ridges) that record the elevation and age of the lake through time. Beach ridges roughly parallel the modern shoreline and preserve the record of highstands of lake level. Geologists cored the ancient beach ridges surrounding Lake Michigan and studied the contents of the cores for elevation data. Using age-dating techniques, they dated the beach ridges back through time and documented the rise and fall of the lake over thousands of years. They discovered that lake level fluctuated in both short-term (decade) and long-term (multi-decade) cycles.

This 1938 aerial photograph of the Gary, Indiana, area shows curved white beach ridges separated by darker areas (wetlands). The photo exposes the gradual northward movement of the Indiana coastline over the past 2,000 years. The curves extending off the beach ridges and into the Grand Calumet River document the position of the mouth of the river as successive ridges were added. Ultimately, the river's outlet was pushed eastward to Marquette Beach.

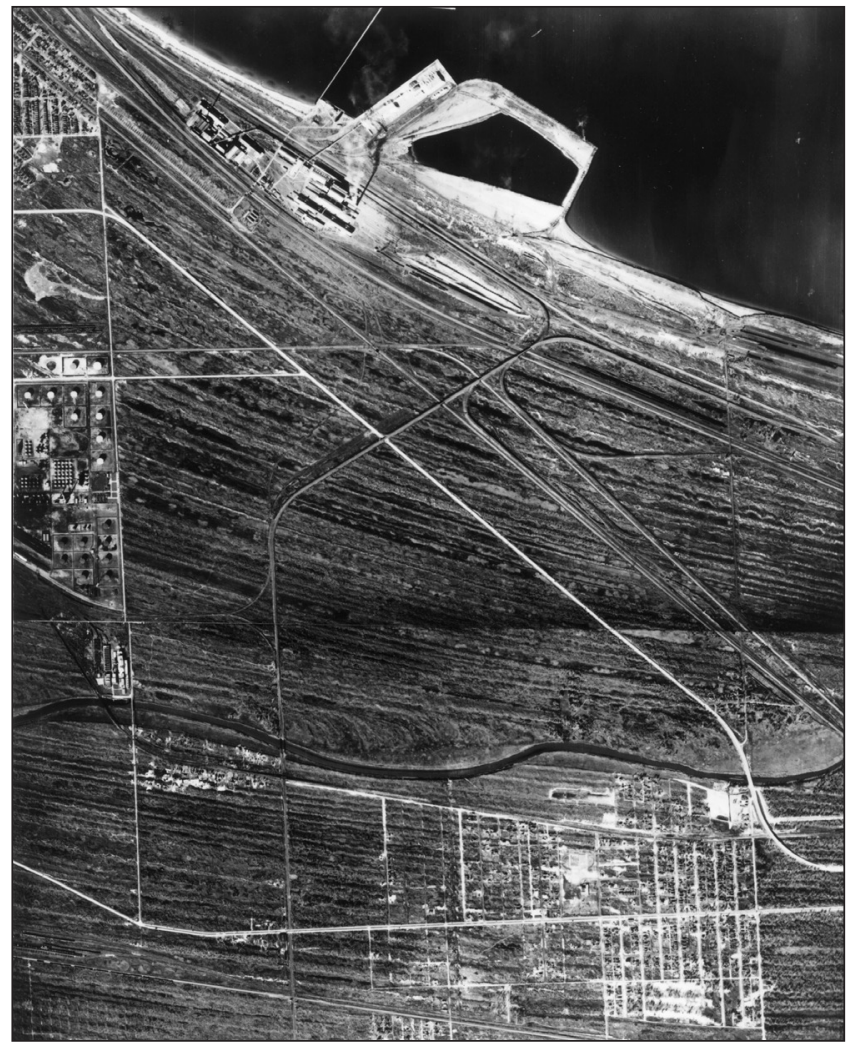

\section{Long-term change}

Geologic studies of Lake Michigan beach ridges indicate that the lake experiences two long-term quasi-periodic fluctuations or cycles. One is about 30 years in duration and the other is about 160 years. Geologists are able to document this behavior throughout the past 4,500 year lake-level record they reconstructed for Lake Michigan. Currently, the elevation of the water in Lake Michigan is peaking on both cycles; in other words, a 30-year-high lake level is coinciding with a 160 -year-high lake level.

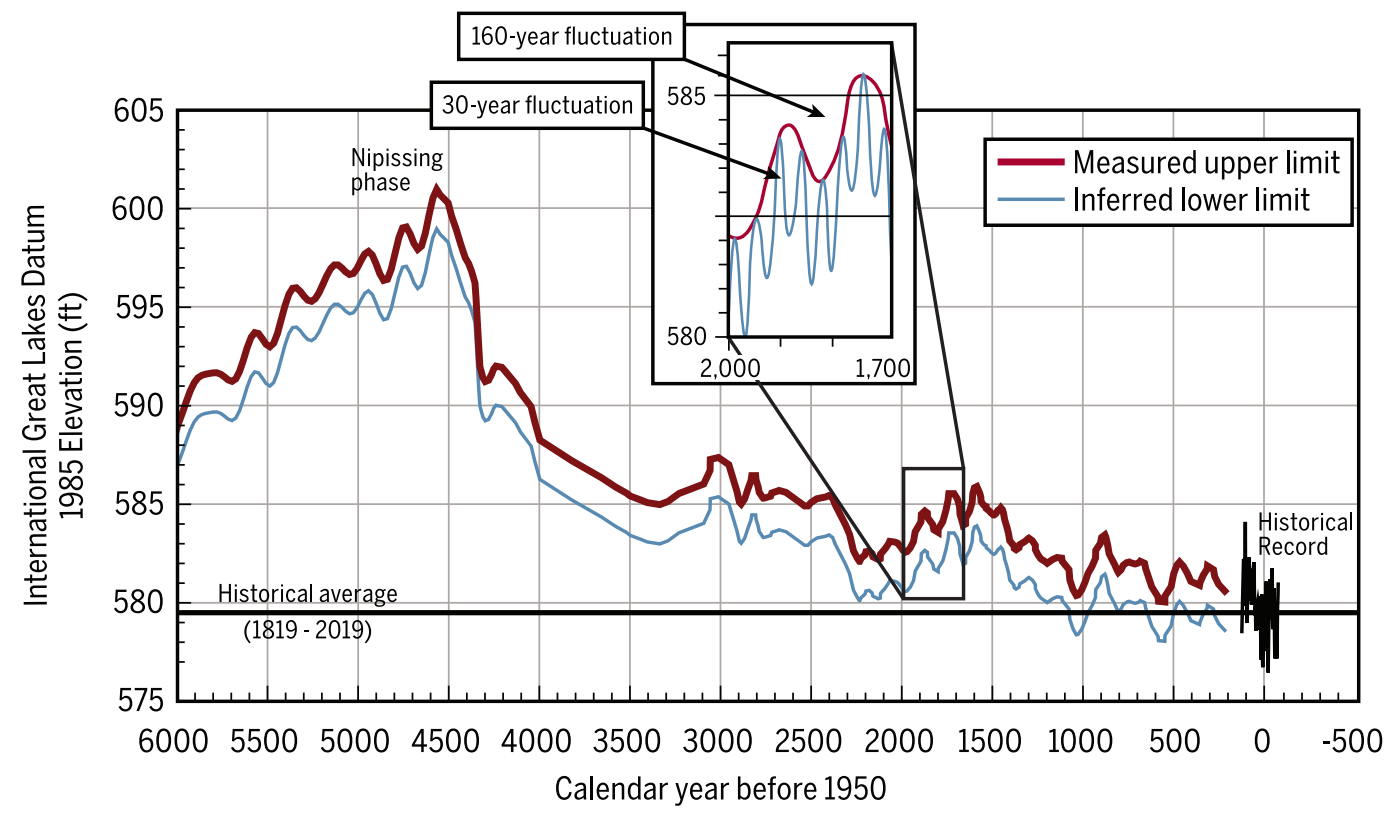

For an overview of the geology of the Lake Michigan coastline studies of lake-level change:
Argyilan, E. P., Johnston, J. W., Lepper, K., Monaghan, G. W., and Thompson, T. A., 2018, Lake-level, shoreline, and dune behavior along the Indiana Southern Shore of Lake Michigan [fieldtrip], in Florea, L. J., ed., Ancient Oceans, Orogenic Uplifts, and Glacial Ice-Geologic Crossroads in America's Heartland: Geological Society of America Field Guide 51, p. 181-203. https://dx.doi.org/10.1130/2018.0051(08)

Baedke, S. J., and Thompson, T. A., 2000, A 4,700-year record of lake level and isostasy for Lake Michigan: Journal of Great Lakes Research, v. 26, n. 4., p. 416-426. https://doi.org/10.1016/S0380-1330(00)70705-2

Thompson, T. A., and Baedke, S. J., 1997, Strandplain evidence for late Holocene lake-level variations in Lake Michigan: Geological Society of America Bulletin, v. 109, p. 666-682. http://dx.doi.org/10.1130/0016-7606(1997)109<0666:SPEFLH>2.3.C0;2 